\title{
29. PETROLOGY OF ULTRAMAFIC ROCKS FROM SITES 556, 558, AND 560 IN THE NORTH ATLANTIC 1
}

\author{
Peter J. Michael, Department of Mineral Sciences, Smithsonian Institution \\ and \\ Enrico Bonatti, Lamont-Doherty Geological Observatory, Columbia University ${ }^{2}$
}

\begin{abstract}
Strongly serpentinized peridotites occur at shallow crustal levels at DSDP Sites 556 (35-Ma-old crust), 558 (35-Maold crust), and 560 (12-Ma-old crust) in the North Atlantic. Primary peridotite silicate minerals are preserved only at Sites 556 and 558, but all three sites have primary spinel preserved. The serpentinites at all three sites were probably spinel harzburgite tectonites, with little or no clinopyroxene.

For orthopyroxene from Site $556, \mathrm{Mg} /(\mathrm{Mg}+\mathrm{Fe})$ ratios average 0.904 , and $\mathrm{Al}_{2} \mathrm{O}_{3}$ contents are about $2.0-3.3$ wt. \% . Compositions of pyroxene-derived bastites from Sites 558 and 560 suggest that the original pyroxenes were probably low-alumina orthopyroxene. Spinels from all three sites have low $\mathrm{Fe}^{3+}$ and $\mathrm{TiO}_{2}$. Spinels from Sites 556 and 560 have high $\mathrm{Cr} /(\mathrm{Cr}+\mathrm{Al})(0.45-0.53)$. Those from Site 558 have $\mathrm{Cr} /(\mathrm{Cr}+\mathrm{Al})$ values that are among the highest measured for any plagioclase-free oceanic peridotites $(0.55-0.62)$.

Whole-rock chemistry, although affected by serpentinization, suggests that the peridotites had relatively low $\mathrm{CaO}$, $\mathrm{TiO}_{2}, \mathrm{Al}_{2} \mathrm{O}_{3}$, and $\mathrm{Na}_{2} \mathrm{O}$. Mineral and whole-rock chemistry and modal abundances suggest that Leg 82 peridotites are residua from partial melting, and that the extent of partial melting may have been greater in this region than farther south in the North Atlantic, or that the mantle was originally more depleted here.
\end{abstract}

\section{INTRODUCTION}

Serpentinized peridotites were recovered at DSDP Sites 556,558 , and 560 (Fig. 1). Site 556 was drilled in 35-Maold crust on a flow line away from the Azores Triple Junction. Peridotites were recovered underneath $461 \mathrm{~m}$ of sediments and $96 \mathrm{~m}$ of basalts. A cemented gabbro breccia directly overlies the serpentinized peridotites, which are interlayered with cemented serpentinite breccias, gabbros, and cemented gabbro breccias from 561-575 m subsurface. Gabbros and cemented gabbro breccias are present from $575 \mathrm{~m}$ to the hole bottom at $639 \mathrm{~m}$, with two narrow serpentinite horizons at about $620 \mathrm{~m}$.

Site 558 was drilled in 35-Ma-old crust on a flow line from the FAMOUS area. Serpentinized peridotites were recovered from $533 \mathrm{~m}$ depth to the hole bottom at 563 $\mathrm{m}$. There are several serpentinite horizons with subtle color and textural differences. They are separated from each other by uncemented serpentinite breccias.

DSDP Site 560 was drilled in 12-Ma-old crust, midway between the Oceanographer and Hayes fracture zones. Serpentinized peridotite was encountered directly under $373 \mathrm{~m}$ of sediments. Two serpentinite horizons, at $373 \mathrm{~m}$ and at about $400 \mathrm{~m}$ depth are separated by gabbros and gabbro breccias.

\section{PETROGRAPHY}

About ten standard $20 \times 30-\mathrm{mm}$ thin sections from Sites 556 and 558 and five from Site 560 were examined. Serpentinites from all three sites had peridotite proto-

\footnotetext{
${ }^{1}$ Bougault, H., Cande, S. C., et al., Init Repts. DSDP, 82: Washington (U.S. Govt. Printing Office).

2 Addresses: (Michael, present address) Department of Geological Science, University of British Columbia, 6339 Storrs Rd., Vancouver V6T 2B4, British Columbia; (Bonatti) Lamont-Doherty Geological Observatory of Columbia University, Palisades, New York 10964.
}

liths. Only those from Site 556 have primary silicates preserved, and even these samples contain no olivine. Primary spinel is preserved in serpentinites from all three sites, however.

Peridotites from the three sites exhibit the pseudomorphic texture that is typical of many oceanic peridotites (Pritchard, 1979). The rock is composed predominantly of mesh-textured serpentine and magnetite. In plane polarized light, the color or tint of the mesh-textured serpentine may vary from clear to light green or brown, and the sharpness of the magnetite framework is also variable. The mesh is the alteration product of olivine, which is generally the least stable phase during serpentinization. Within the mesh matrix are large (up to $10 \mathrm{~mm}$ ) bastites or serpentinized pyroxene porphyroclast relics, which preserve the shape and fine details of the internal structure of the pyroxene, including kink-banding and exsolution lamellae.

It is difficult to discern the difference between orthopyroxene bastite and clinopyroxene bastite, or to reconstruct the original modes of the samples. Samples from Site 556 have islands of orthopyroxene preserved within the bastites. Small blebs of clinopyroxene, exsolved from the orthopyroxene in these samples, suggest that clinopyroxene was more resistant than orthopyroxene to serpentinization. The lack of clinopyroxene porphyroclasts is therefore a primary feature of the peridotite from Site 556. Sites 558 and 560 required a less direct approach for modal reconstruction. Petrographic and microprobe analysis of partly serpentinized peridotites from other locations (the Owen Fracture Zone), in which clinopyroxene and orthopyroxene porphyroclasts and their enclosing bastites are preserved, suggests that clinopyroxene bastite often has a different appearance than orthopyroxene bastite. For example, relict exsolution lamellae 


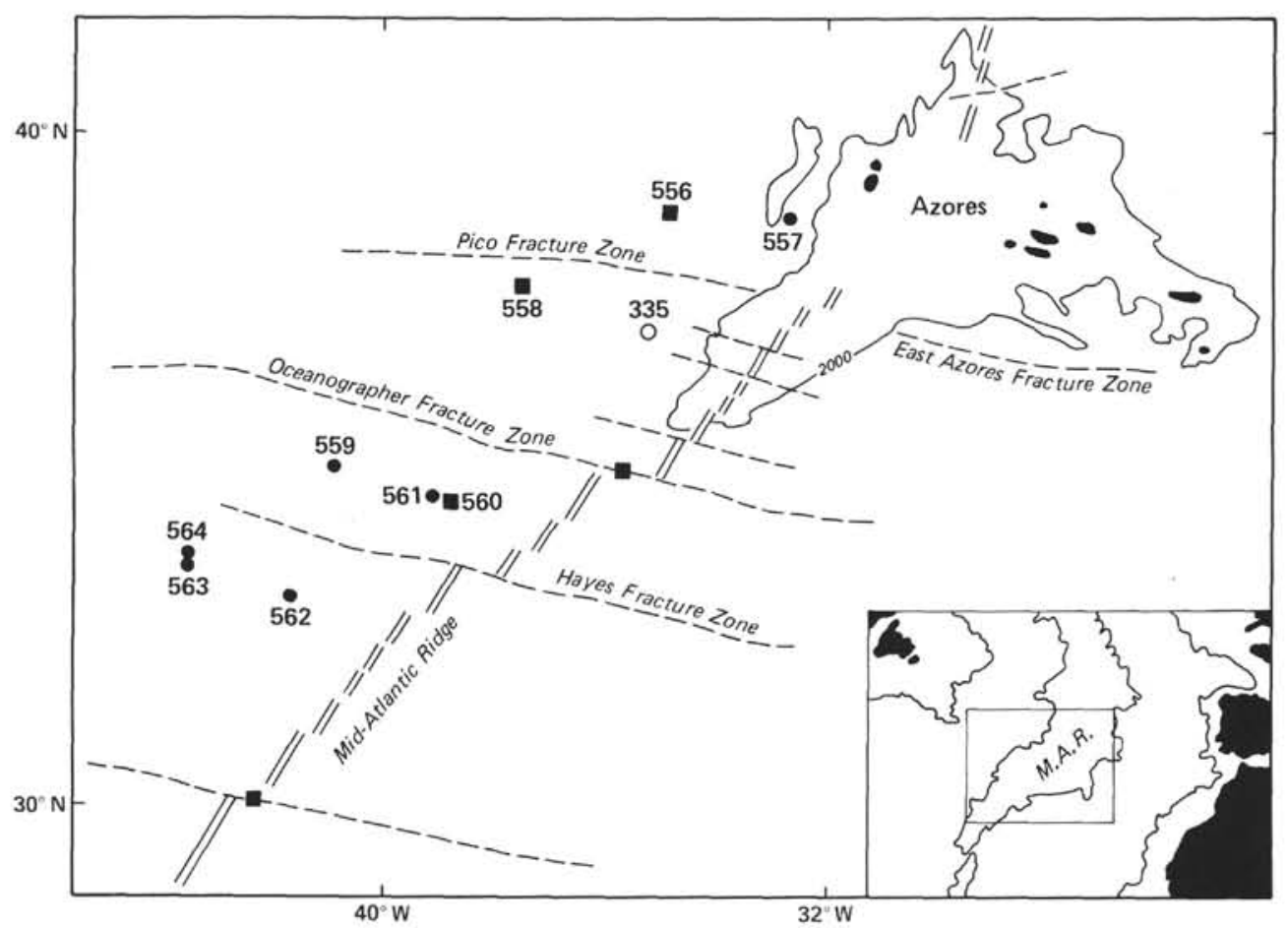

Figure 1. Locations of peridotite recoveries (solid squares), DSDP Leg 82, and surrounding region.

often "die out" toward the edges of clinopyroxene bastites. Clinopyroxene porphyroclasts generally have higher $\mathrm{Cr}$ contents than coexisting orthopyroxene porphyroclasts, and $\mathrm{Cr}$ concentrations and concentration differences are reflected in the bastites as well (Bonatti et al., in preparation ${ }^{3}$ ). With these observations in mind, we examined the bastites from Sites 558 and 560, and approximately 20 bastites from two sections of each site were analyzed for $\mathrm{Cr}$ content. The observations suggest that little or no porphyroclastic clinopyroxene was present in peridotites from Sites 558 and 560. Thus, even though the silicates have been completely serpentinized, it is possible to infer original peridotite modes and textures (Table 1). The reconstructions suggest that the samples were originally spinel harzburgite tectonites.

Spinel is preserved in all of the serpentinized peridotites. It is generally brick-red, with a varied habit, shape and association and is often contained within or near orthopyroxene or orthopyroxene bastite. In this association, spinel forms as long, curved grains (up to $8 \mathrm{~mm}$ ) with xenomorphic texture around orthopyroxene; as symplectic textured clusters of small grains $(0.1-0.5 \mathrm{~mm})$; and as small grains near orthopyroxene. Similar associations of spinel with orthopyroxene in peridotites have been described by other authors (Hamlyn and Bonatti, 1980; Smith, 1977) and ascribed to the reaction: olivine + garnet $\rightarrow$ spinel + pyroxene. Spinel also occurs within the olivine-derived mesh-textured serpentine, as rounded or rectangular porphyroclasts $(0.3-3 \mathrm{~mm})$ or as tiny $(0.1-0.3 \mathrm{~mm})$ disrupted grains scattered throughout a larger $(\sim 1 \mathrm{~cm})$ region.

\footnotetext{
${ }^{3}$ Bonatti, E., Morandi, N., Brueckner, H., and Michael, P. J., Progressive serpentization of mantle-derived ultramafic rocks from the Owen Fracture Zone.
}

Table 1. Modal abundance estimates (reconstructed).

\begin{tabular}{lccccc}
\hline \multicolumn{1}{c}{ Location } & Olivine & Orthopyroxene & Clinopyroxene & Spinel & $\begin{array}{c}\text { Number of } \\
\text { samples }\end{array}$ \\
\hline Site $556\left(-39^{\circ} \mathrm{N}\right)$ & 83 & 16 & 0.5 & 1 & 7 \\
Site $558\left(-37^{\circ} \mathrm{N}\right)$ & 77 & 22 & 0 & 0.6 & 11 \\
Site $560\left(-34^{\circ} \mathrm{N}\right)$ & 78 & 22 & 0 & 0.2 & 4 \\
Oceanographer F.Z. $\left(35^{\circ} \mathrm{N}\right)$ & 80 & 19 & 0.1 & 0.5 & 27 \\
Atlantis F.Z. $\left(30^{\circ} \mathrm{N}\right)$ & 65 & 30 & 5 & 1 & 11 \\
Kane F.Z. $\left(24^{\circ} \mathrm{N}\right)$ & 64 & 33 & 1 & 1.5 & 7 \\
Site $395\left(23^{\circ} \mathrm{N}\right)$ & 59 & 32 & 6 & 3 & a \\
\hline
\end{tabular}

Note: Modal estimates largely from pseudo morphic-textured serpentinites, 400 points were counted for each sample (a standard $20 \times 30-\mathrm{mm}$ thin section). Data sources are the same as in Figure 2. F.Z. = Fracture Zone.
a Data from Sinton, 1979.

Opaque spinel is present in three associations: (1) with clinopyroxene and plagioclase $\left(\mathrm{An}_{65}\right)$, a probable gabbroic inclusion; (2) as an alteration product along the edges and cracks in red spinel; and (3) as complete grains, possibly also as a reaction product.

Veins of calciferous and noncalciferous amphiboles are variably present in the peridotites. Where they cut the rock, the nearby pyroxenes have been transformed into predominant amphibole and lesser serpentine. This may represent an earlier, high-temperature hydration of the original peridotite, and the amphibole may be more resistant to serpentinization than the primary, anhydrous silicates.

\section{MINERAL CHEMISTRY}

Mineral compositions were obtained with an automated, three-channel ARL-EMX microprobe at LamontDoherty Geological Observatory, using a $15-\mathrm{kV}$ accelerating voltage, and a $0.15 \mu \mathrm{A}$ beam current. Data were reduced online using a Bence-Albee procedure and reference to a suite of natural and synthetic mineral standards. For spinel analyses, a narrow (3-5 $\mu \mathrm{m})$ beam was 
used. $\mathrm{Fe}^{2+}$ and $\mathrm{Fe}^{3+}$ were calculated assuming stoichiometry. A broad $(70 \mu \mathrm{m})$ microbeam was used to obtain a more representative analysis of the heterogeneous orthopyroxenes and bastites. The mineral compositions presented in Tables 2-4 are based on averages of more than four spot analyses in each of two separate grains.

Orthopyroxene. Site 556 peridotites have orthopyroxenes with high and variable $\mathrm{Mg} /(\mathrm{Mg}+\mathrm{Fe})$ ratios, averaging 0.904 (Table 2). These ratios are slightly higher than those of pyroxenes from the Vema Fracture Zone (Hamlyn, unpublished data, 1982) and DSDP Site 395 (Sinton, 1979), but similar to those from the Kane and Atlantis fracture zones. The ratios are lower than orthopyroxenes from the Oceanographer Fracture Zone (Fig. 2).

Orthopyroxene alumina contents are quite low, averaging only $2.8 \%$ (Table 2 ). Site 556 orthopyroxenes contain less alumina than orthopyroxenes from most other oceanic peridotites, a feature shared by some other North Atlantic peridotites (Fig. 3). Site 556 orthopyroxenes approach the compositions of pyroxenes from some alpine peridotites, which are probably more depleted than oceanic peridotites (Dick, 1975). Chrome concentrations are quite high, about $1 \%$, and $\mathrm{Cr} /(\mathrm{Cr}+\mathrm{Al})$ is about $0.16-$ 0.19 ; higher than other oceanic peridotites because of the low alumina. Orthopyroxene has about 3-5 mole\% wollastonite component, which is similar to orthopyroxene of other oceanic peridotites. Measurement of this quantity is difficult because of the large-scale heterogeneity caused by exsolution.

Bastites of serpentinites from Sites 558 and 560 have very low alumina concentrations, about $1.2-2 \%$. Preliminary work (Bonatti et al., in preparation) suggests that bastite's alumina content reflects to some degree the alumina content of the original pyroxene from which it derives, and that $\mathrm{Al}$ has limited mobility during the

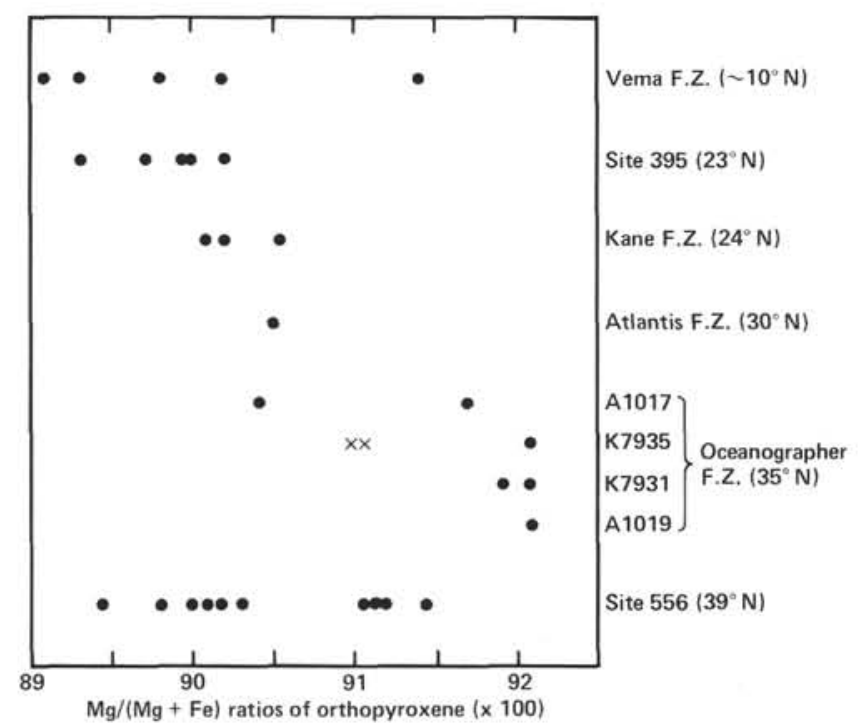

Figure $2 . \mathrm{Mg} /(\mathrm{Mg}+\mathrm{Fe})$ ratios of orthopyroxenes from Sites 395 and 556, and other North Atlantic and equatorial Atlantic sites. F. Z. = Fracture Zone. Data sources are: Vema Fracture Zone, Hamlyn and Bonatti, unpublished data; Site 395, Sinton (1979); Kane, Atlantis, and Oceanographer fracture zones, Michael and Bonatti, unpublished data. x's are coexisting olivines. serpentinization process. Thus, orthopyroxenes from Sites 558 and 560 may have also had low alumina.

Clinopyroxene. In serpentinized peridotites from Site 556 , clinopyroxene occurs mostly as tiny $(0.1-0.5 \mathrm{~mm})$ blebs included within or spatially associated with much larger orthopyroxenes or orthopyroxene bastites. These are most likely exsolution products from the orthopyroxene. In one sample (556-13-1, 6-8 cm), a large primary clinopyroxene grain is associated with plagioclase $\sim \mathrm{An}_{65}$, and high-Ti spinel. This assemblage might be an inclusion from the surrounding gabbros, since the interval is adjacent to a gabbro breccia.

Exsolved clinopyroxene has high $\mathrm{Mg} /(\mathrm{Mg}+\mathrm{Fe})$ ratios (0.907-0.921) and low alumina contents (2.30-4.48 wt.\%) (Table 3 ). $\mathrm{TiO}_{2}$ and $\mathrm{Na}_{2} \mathrm{O}$ are positively correlated and quite variable. Chrome contents (about $1 \%$ ) are lower than those observed from nonexsolved clinopyroxenes from other oceanic peridotites (Sinton, 1979).

Spinel. Spinels have variable and high $\mathrm{Cr}$ concentrations and very low $\mathrm{Ti}$ and $\mathrm{Fe}^{3+}$ (calculated assuming stoichiometry; Table 4). Spinels from Site 558 are among the most chromium-rich spinels measured for any oceanic peridotites $(\mathrm{Cr} /[\mathrm{Cr}+\mathrm{Al}] \sim 0.58)$, and spinels from Site 556 and 560 are only slightly less chromium rich (Fig. 4).

Opaque spinel, which is associated with plagioclase and clinopyroxene, has high $\mathrm{TiO}_{2}$ (up to $3 \mathrm{wt} . \%$ ) and $\mathrm{Fe}^{3+}$ and is more similar to spinel, which is in equilibrium at low pressure in basalts (Sigurdsson and Schilling, 1976). Opaque spinel that invades cracks and margins of brick red spinel approaches pure magnetite in composition. The third association of opaque spinel, as discrete grains, is slightly more iron-rich than coexisting brick-red spinel in a similar association, and underscores the fact that spinel compositions vary within individual grains and between grains within thin section. The significance of the variation is not clear, but has been ascribed (Hamlyn and Bonatti, 1980) to subsolidus reequilibration by the reaction: orthopyroxene + clinopyroxene + Al-spinel $\rightarrow$ olivine + plagioclase $+\mathrm{Cr}$-spinel. Recently, Ozawa (1983b) noted that intergrain and intragrain variations in spinel chemistry arose from incomplete reequilibration of spinel with surrounding pyroxenes and olivine. Spinel compositional variation can also arise from the serpentinization reaction (Hoffman and Walker, 1978). Thus, the spinel compositional variation that is observed between different drilling sites or fracture zones may reflect the variation of the original peridotite protolith, or possibly later reactions.

\section{WHOLE-ROCK MAJOR ELEMENT CHEMISTRY}

Major element compositions were determined by standard X-ray fluorescence (XRF) methods, using a Siemens SRS-1 spectrometer and employing the sample preparation procedures of Harvey and others (1973). The results are shown in Table 5. Evaluation of these data must take into account that the samples are highly serpentinized, and that serpentinization, in addition to increasing the water content of the rock, may involve some elemental exchange.

The relatively high $\mathrm{CaO}$ and LOI in Samples 556$14-1,61-65 \mathrm{~cm}$ and $558-41-3,111-116 \mathrm{~cm}$ are due to 
Table 2. Selected microprobe analyses of orthopyroxene from Hole 556 peridotites.

\begin{tabular}{|c|c|c|c|c|c|c|c|c|c|}
\hline $\begin{array}{l}\text { Core-Section } \\
\text { (interval in } \mathrm{cm} \text { ) }\end{array}$ & $\begin{array}{c}13-1 \\
60-75\end{array}$ & $\begin{array}{c}13-1 \\
6-8\end{array}$ & $\begin{array}{c}13-1 \\
6-8\end{array}$ & $\begin{array}{c}14-1 \\
61-63\end{array}$ & $\begin{array}{c}14-1 \\
110-111\end{array}$ & $\begin{array}{c}14-1 \\
116-118\end{array}$ & $\begin{array}{c}14-2 \\
79-82\end{array}$ & $\begin{array}{c}14-2 \\
115-121\end{array}$ & $\begin{array}{c}14-2 \\
115-121\end{array}$ \\
\hline \multicolumn{10}{|c|}{ Major elements (wt.\%) } \\
\hline $\mathrm{SiO}_{2}$ & 55.46 & 56.42 & 55.57 & 55.08 & 55.63 & 55.34 & 54.81 & 55.74 & 54.94 \\
\hline $\mathrm{TiO}_{2}$ & 0.00 & 0.03 & 0.19 & 0.01 & 0.03 & 0.00 & 0.01 & 0.00 & 0.00 \\
\hline $\mathrm{Al}_{2} \mathrm{O}_{3}$ & 2.75 & 2.83 & 2.19 & 2.83 & 2.64 & 2.90 & 3.30 & 2.66 & 2.83 \\
\hline $\mathrm{Cr}_{2} \mathrm{O}_{3}$ & 0.91 & 1.00 & 0.65 & 0.87 & 0.90 & 0.95 & 0.85 & 0.70 & 0.85 \\
\hline $\mathrm{FeO}^{-}$ & 5.55 & 5.70 & 7.06 & 5.53 & 6.71 & 6.59 & 6.44 & 6.47 & 6.39 \\
\hline $\mathrm{MnO}$ & 0.13 & 0.15 & 0.19 & 0.16 & 0.14 & 0.16 & 0.14 & 0.14 & 0.16 \\
\hline $\mathrm{NiO}$ & 0.02 & 0.02 & 0.08 & 0.13 & 0.01 & 0.11 & 0.03 & 0.05 & 0.09 \\
\hline $\mathrm{MgO}$ & 32.03 & 32.04 & 33.04 & 32.86 & 31.97 & 32.56 & 32.46 & 33.30 & 32.62 \\
\hline $\mathrm{CaO}$ & 2.60 & 2.80 & 1.88 & 2.93 & 2.33 & 2.13 & 2.45 & 1.64 & 2.38 \\
\hline Total & 99.45 & 100.99 & 100.85 & 100.40 & 100.36 & 100.74 & 100.49 & 100.70 & 100.26 \\
\hline \multicolumn{10}{|c|}{ Cations on the basis of 6 oxygens } \\
\hline $\mathrm{Si}$ & 1.933 & 1.943 & 1.922 & 1.908 & 1.930 & 1.914 & 1.901 & 1.922 & 1.910 \\
\hline $\mathrm{Ti}$ & 0.000 & 0.001 & 0.005 & 0.000 & 0.001 & 0.000 & 0.000 & 0.000 & 0.000 \\
\hline Al & 0.113 & 0.114 & 0.089 & 0.116 & 0.108 & 0.118 & 0.135 & 0.108 & 0.116 \\
\hline $\mathrm{Cr}$ & 0.025 & 0.027 & 0.018 & 0.024 & 0.025 & 0.026 & 0.023 & 0.019 & 0.023 \\
\hline $\mathrm{Fe}^{*}$ & 0.162 & 0.163 & 0.204 & 0.160 & 0.195 & 0.191 & 0.187 & 0.187 & 0.186 \\
\hline $\mathrm{Mn}$ & 0.004 & 0.004 & 0.006 & 0.005 & 0.004 & 0.005 & 0.004 & 0.004 & 0.005 \\
\hline $\mathrm{Ni}$ & 0.001 & 0.001 & 0.002 & 0.004 & 0.000 & 0.003 & 0.001 & 0.001 & 0.003 \\
\hline $\mathrm{Mg}$ & 1.664 & 1.630 & 1.703 & 1.697 & 1.653 & 1.678 & 1.678 & 1.712 & 1.690 \\
\hline $\mathrm{Ca}$ & 0.097 & 0.102 & 0.070 & 0.109 & 0.087 & 0.079 & 0.091 & 0.061 & 0.089 \\
\hline Total & 3.999 & 3.985 & 4.019 & 4.023 & 4.003 & 4.014 & 4.020 & 4.014 & 4.022 \\
\hline $\mathrm{Mg} /(\mathrm{Mg}+\mathrm{Fe})$ & 0.91 & 0.909 & 0.893 & 0.914 & 0.894 & 0.898 & 0.900 & 0.902 & 0.901 \\
\hline En & 86.54 & 86.01 & 86.15 & 86.32 & 85.46 & 86.16 & 85.79 & 87.38 & 86.03 \\
\hline Fs & 8.41 & 8.59 & 10.33 & 8.15 & 10.06 & 9.78 & 9.55 & 9.53 & 9.46 \\
\hline Wo & 5.05 & 5.40 & 3.52 & 5.53 & 4.48 & 4.05 & 4.65 & 3.09 & 4.51 \\
\hline
\end{tabular}

Note: All iron $\left(\mathrm{Fe}^{*}\right)$ is assumed to be $\mathrm{Fe}^{2+}$.

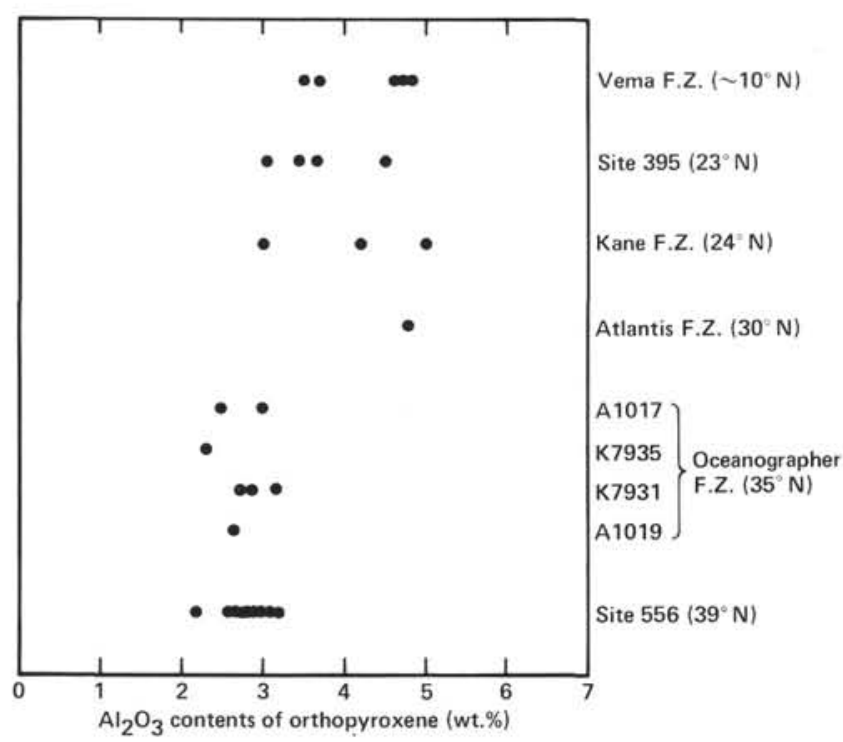

Figure 3. $\mathrm{Al}_{2} \mathrm{O}_{3}$ contents of orthopyroxenes from Sites 395 and 556 , and other North Atlantic and equatorial Atlantic sites. F. Z. = Fracture Zone. Data sources are the same as Figure 2.

carbonate veins in the sample. Thus, in these two samples loss on ignition (LOI) must include significant quantities of carbonate-derived $\mathrm{CO}_{2}$. If the data are recalculated on a LOI-free basis, the $\mathrm{Al}_{2} \mathrm{O}_{3}$ content of all samples, which should not be greatly affected by serpentinization, appears to be low compared to other oceanic serpentinites, paralleling the low $\mathrm{Al}$ content of orthopyroxenes, clinopyroxenes, and bastites. $\mathrm{CaO}, \mathrm{K}_{2} \mathrm{O}$, and $\mathrm{Na}_{2} \mathrm{O}$ are also rather low, but these elements, particularly $\mathrm{CaO}$, are probably affected by serpentinization.

\section{DISCUSSION}

The following points can be drawn from the study of the ultramafic rocks recovered during DSDP Leg 82 .

1. The rocks appear to be spinel harzburgites and to have undergone intense serpentinization. Their relict textures and the chemistry of relict pyroxene and spinel suggest they are tectonites of upper mantle derivation.

2. Pyroxenes have low $\mathrm{Al}$ content, which might be related to greater extent of melting compared to other analyzed oceanic ultramafics (Mysen and Kirshiro, 1977; Jaques and Green, 1980). Relatively high $\mathrm{Mg} /(\mathrm{Mg}+$ $\mathrm{Fe}$ ) and low $\mathrm{Na}$ contents both of pyroxenes and of whole rock suggest that we are dealing with residual material, depleted of a basaltic fraction.

3. Spinels are in general rich in $\mathrm{Cr}$, but their composition is variable in these rocks, suggesting that their equilibrium with surrounding pyroxenes and olivine was incomplete. Although spinel composition may be related to the serpentinization process, its correlation with modal abundance of pyroxene suggests that it is primarily a function of the peridotite protolith composition.

4. Ultramafic rocks from DSDP Sites 556, 558, and 560 , recovered in crust $35 \mathrm{Ma}$ old (556 and 558) and 12 Ma old (560), are rather similar to those from Site 395, recovered in crust about $7 \mathrm{Ma}$ old, though the latter con- 
Table 3. Selected microprobe analyses of clinopyroxene from Hole 556 peridotites.

\begin{tabular}{|c|c|c|c|c|c|}
\hline $\begin{array}{l}\text { Core-Section } \\
\text { (interval in } \mathrm{cm} \text { ) }\end{array}$ & $\begin{array}{l}13-1 \\
60-75\end{array}$ & $\begin{array}{l}13-1 \\
6-8\end{array}$ & $\begin{array}{c}14-1 \\
110-111\end{array}$ & $\begin{array}{c}14-1 \\
116-118\end{array}$ & $\begin{array}{c}14-2 \\
115-121\end{array}$ \\
\hline \multicolumn{6}{|c|}{ Major elements (wt.\%) } \\
\hline $\mathrm{SiO}_{2}$ & 52.57 & 53.16 & 53.44 & 51.87 & 53.60 \\
\hline $\mathrm{TiO}_{2}$ & 0.01 & 0.78 & 0.73 & 0.14 & 0.03 \\
\hline $\mathrm{Al}_{2} \mathrm{O}_{3}$ & 4.48 & 2.30 & 2.96 & 3.72 & 3.05 \\
\hline $\mathrm{Cr}_{2} \mathrm{O}_{3}$ & 1.21 & 0.11 & 1.06 & 1.46 & 1.15 \\
\hline $\mathrm{FeO}^{\circ}$ & 2.62 & 3.22 & 2.76 & 2.67 & 2.63 \\
\hline $\mathrm{MnO}$ & 0.08 & 0.11 & 0.07 & 0.13 & 0.11 \\
\hline $\mathrm{NiO}$ & 0.00 & 0.05 & 0.00 & 0.07 & 0.03 \\
\hline $\mathrm{MgO}$ & 17.00 & 17.92 & 17.66 & 16.97 & 17.26 \\
\hline $\mathrm{CaO}$ & 22.98 & 22.29 & 21.59 & 22.57 & 22.92 \\
\hline $\mathrm{Na}_{2} \mathrm{O}$ & 0.04 & 0.31 & 0.42 & 0.38 & 0.23 \\
\hline Total & 100.99 & 100.25 & 100.69 & 99.98 & 101.01 \\
\hline
\end{tabular}

Cations on the basis of 6 oxygens

\begin{tabular}{lrrrrr}
$\mathrm{Si}$ & 1.891 & 1.928 & 1.923 & 1.892 & 1.928 \\
$\mathrm{Ti}$ & 0.000 & 0.021 & 0.020 & 0.004 & 0.001 \\
$\mathrm{Al}$ & 0.190 & 0.098 & 0.126 & 0.160 & 0.129 \\
$\mathrm{Cr}$ & 0.034 & 0.003 & 0.030 & 0.042 & 0.033 \\
$\mathrm{Fe}$ & 0.079 & 0.098 & 0.083 & 0.081 & 0.079 \\
$\mathrm{Mn}$ & 0.002 & 0.003 & 0.002 & 0.004 & 0.003 \\
$\mathrm{Ni}$ & 0.000 & 0.001 & 0.000 & 0.002 & 0.001 \\
$\mathrm{Mg}$ & 0.912 & 0.969 & 0.947 & 0.923 & 0.925 \\
$\mathrm{Ca}$ & 0.886 & 0.866 & 0.833 & 0.882 & 0.883 \\
$\mathrm{Na}$ & 0.003 & 0.022 & 0.029 & 0.027 & 0.016 \\
$\mathrm{Total}$ & 3.997 & 4.011 & 3.994 & 4.017 & 3.998 \\
$\mathrm{Mg} /(\mathrm{Mg}+\mathrm{Fe})$ & 0.920 & 0.908 & 0.919 & 0.919 & 0.921 \\
& & & & & \\
$\mathrm{En}$ & 48.59 & 50.13 & 50.85 & 48.92 & 49.02 \\
$\mathrm{Fs}$ & 4.20 & 5.05 & 4.46 & 4.32 & 4.19 \\
$\mathrm{Wo}$ & 47.21 & 44.82 & 44.69 & 46.77 & 46.79 \\
\hline
\end{tabular}

Note: All except 13-1, 6-8 cm are exsolution blebs from much larger orthopyroxene. All iron ( $\mathrm{Fe}^{*}$ ) is assumed to be $\mathrm{Fe}^{2+}$ sist of lherzolite in addition to harzburgite (Sinton, 1979; Arai and Fujii, 1979) and seem to be less refractory than the Leg 82 samples.

5. The recoveries of ultramafic rocks at relatively shallow levels in the crust away from transform zones confirms earlier suggestions that mantle-derived ultramafic bodies are an important component of slow spreading, Atlantic-type crust. The complex stratigraphy at Holes 556,558 , and 560 suggests a major role of faulting in the shallow emplacement of ultramafics in the crust, as proposed by Bonatti (1976) and Francis (1981). The observation that peridotite tectonites are sandwiched between gabbro layers suggests that only the topmost layer of peridotites is being sampled.

6. Comparison of ultramafics from non-fracture-zone Sites 556, 558, and 560 with ultramafics recovered from nearby fracture zones (i.e., Oceanographer Fracture Zone at $35^{\circ} \mathrm{N}$, see Fig. 1) suggests that fracture zones contain some ultramafic rocks that are slightly less refractory than ultramafic rocks recovered in nearby non-fracturezone crust. This observation is supported by studies at DSDP Site 395 and the Kane Fracture Zone at about $24^{\circ}$ (Michael and Bonatti, in preparation ${ }^{4}$ ). It is possible that the upper mantle associated with fracture zones may have undergone less extensive melting than nearby upper mantle material (Michael and Bonatti, in preparation). Similarly, comparison between Leg 82 and Oceanographer Fracture Zone ultramafics with ultramafics from farther south in the Atlantic (see, for instance, Fig. 4),

\footnotetext{
${ }^{4}$ Michael, P. J., and Bonatti, E., Regional and tectonic variations of oceanic ultramafic rocks from the North Atlantic.
}

Table 4. Selected microprobe analyses of nonopaque spinels from peridotites of Sites 556, 558, and 560.

\begin{tabular}{|c|c|c|c|c|c|c|c|c|c|c|}
\hline \multirow{2}{*}{$\begin{array}{c}\text { Hole } \\
\text { Core-Section } \\
\text { (interval in } \mathrm{cm} \text { ) }\end{array}$} & \multicolumn{4}{|c|}{556} & \multicolumn{4}{|c|}{558} & \multicolumn{2}{|c|}{560} \\
\hline & $\begin{array}{l}13-1 \\
1-3\end{array}$ & $\begin{array}{c}14-1 \\
116-118\end{array}$ & $\begin{array}{c}14-2 \\
78-84\end{array}$ & $\begin{array}{c}14-2 \\
114-122\end{array}$ & $\begin{array}{c}42-1 \\
49-51\end{array}$ & $\begin{array}{c}42-1 \\
122-129\end{array}$ & $\begin{array}{c}43-1 \\
43-47\end{array}$ & $\begin{array}{l}44-1 \\
4-7\end{array}$ & $\begin{array}{c}4-1 \\
60-65\end{array}$ & $\begin{array}{c}5-1 \\
81-84\end{array}$ \\
\hline \multicolumn{11}{|c|}{ Major elements (wt.\%) } \\
\hline $\mathrm{TiO}_{2}$ & 0.30 & 0.00 & 0.12 & 0.00 & 0.11 & 0.00 & 0.24 & 0.00 & 0.02 & 0.00 \\
\hline $\mathrm{Cr}_{2} \mathrm{O}_{3}$ & 41.64 & 37.11 & 38.46 & 36.90 & 45.33 & 45.01 & 45.51 & 46.61 & 40.46 & 40.11 \\
\hline $\mathrm{Al}_{2} \mathrm{O}_{3}$ & 25.31 & 29.66 & 28.43 & 31.05 & 22.20 & 25.41 & 22.80 & 22.38 & 28.75 & 29.96 \\
\hline $\mathrm{Fe}_{2} \mathrm{O}_{3}$ & 3.63 & 3.30 & 2.98 & 1.65 & 3.30 & 1.43 & 2.20 & 2.09 & 2.15 & 1.02 \\
\hline $\mathrm{FeO}$ & 14.55 & 15.32 & 16.73 & 15.43 & 17.08 & 14.97 & 17.29 & 15.99 & 14.38 & 14.22 \\
\hline $\mathrm{MnO}$ & 0.21 & 0.33 & 0.29 & 0.27 & 0.38 & 0.34 & 0.34 & 0.33 & 0.27 & 0.25 \\
\hline $\mathrm{MgO}$ & 13.95 & 13.63 & 12.60 & 13.99 & 11.75 & 13.68 & 11.91 & 12.86 & 14.32 & 14.89 \\
\hline Total & 99.59 & 99.35 & 99.61 & 99.29 & 100.15 & 100.84 & 100.29 & 100.26 & 100.35 & 100.45 \\
\hline \multicolumn{11}{|c|}{ Cations on the basis of 4 oxygens } \\
\hline $\mathrm{Ti}$ & 0.007 & 0.000 & 0.003 & 0.000 & 0.003 & 0.000 & 0.006 & 0.000 & 0.000 & 0.000 \\
\hline $\mathrm{Cr}$ & 0.998 & 0.879 & 0.918 & 0.867 & 1.111 & 1.069 & 1.110 & 1.136 & 0.949 & 0.933 \\
\hline $\mathrm{Al}$ & 0.904 & 1.047 & 1.013 & 1.087 & 0.811 & 0.900 & 0.829 & 0.810 & 1.005 & 1.039 \\
\hline $\mathrm{Fe}^{3+}$ & 0.083 & 0.074 & 0.068 & 0.037 & 0.077 & 0.032 & 0.051 & 0.048 & 0.048 & 0.023 \\
\hline $\mathrm{Fe}^{2+}$ & 0.369 & 0.384 & 0.423 & 0.384 & 0.443 & 0.376 & 0.446 & 0.411 & 0.357 & 0.350 \\
\hline $\mathrm{Mn}$ & 0.005 & 0.008 & 0.007 & 0.007 & 0.010 & 0.009 & 0.009 & 0.009 & 0.007 & 0.006 \\
\hline $\mathrm{Mg}$ & 0.630 & 0.608 & 0.567 & 0.620 & 0.543 & 0.613 & 0.548 & 0.589 & 0.633 & 0.653 \\
\hline $\mathrm{Cr}$ & \multirow[t]{2}{*}{0.525} & \multirow[t]{2}{*}{0.456} & \multirow[t]{2}{*}{0.475} & \multirow[t]{2}{*}{0.444} & \multirow[t]{2}{*}{0.578} & \multirow[t]{2}{*}{0.543} & \multirow[t]{2}{*}{0.572} & \multirow[t]{2}{*}{0.584} & \multirow[t]{2}{*}{0.486} & \multirow[t]{2}{*}{0.473} \\
\hline $\mathrm{Cr}+\mathrm{Al}$ & & & & & & & & & & \\
\hline $\mathrm{Mg}$ & \multirow[t]{2}{*}{0.630} & \multirow[t]{2}{*}{0.613} & \multirow[t]{2}{*}{0.573} & \multirow[t]{2}{*}{0.618} & \multirow[t]{2}{*}{0.551} & \multirow[t]{2}{*}{0.620} & \multirow[t]{2}{*}{0.551} & \multirow[t]{2}{*}{0.589} & \multirow[t]{2}{*}{0.639} & \multirow[t]{2}{*}{0.651} \\
\hline $\mathrm{Mg}+\mathrm{Fe}^{2+}$ & & & & & & & & & & \\
\hline
\end{tabular}

Note: $\mathrm{Fe}^{2+}$ and $\mathrm{Fe}^{3+}$ calculated assuming stoichiometry. 


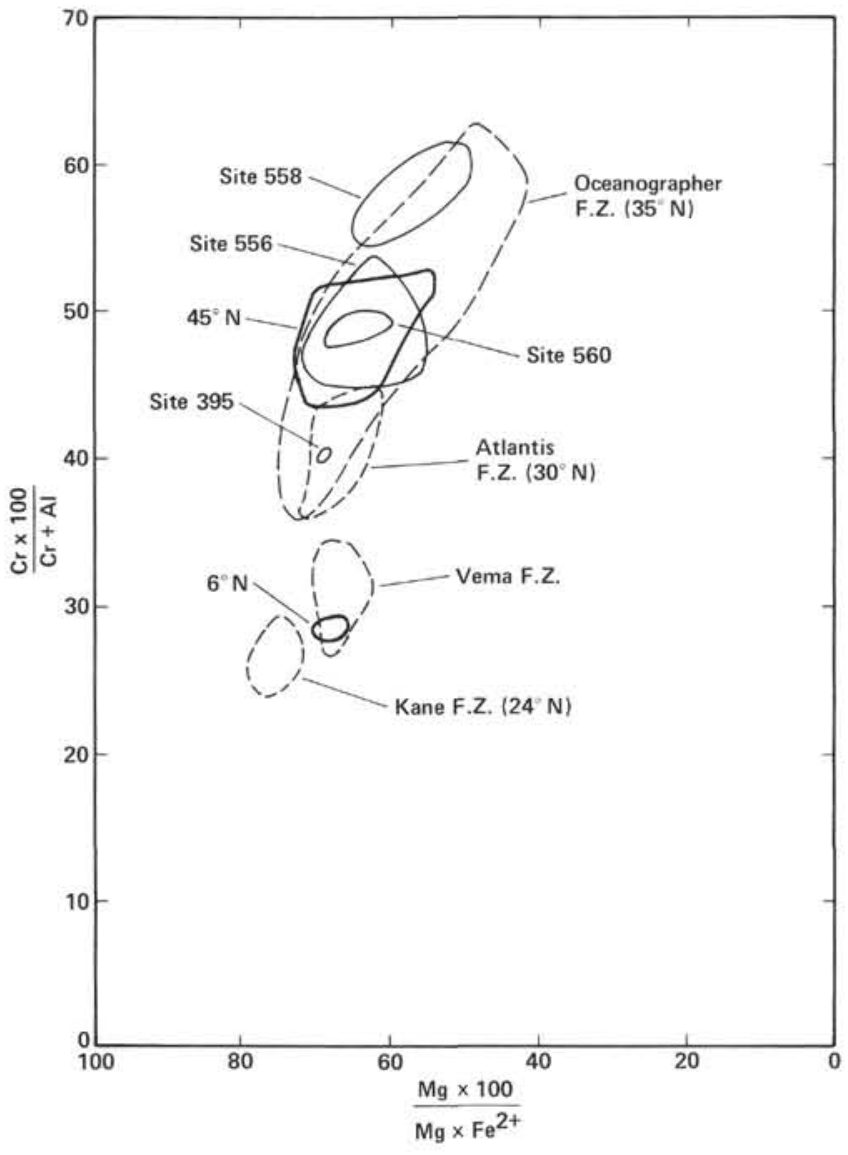

Figure 4. Spinel compositional variation in oceanic mantle-derived peridotites. Data sources are the same as Figure 2, plus $6^{\circ} \mathrm{N}$, Michael and Bonatti, unpublished data; $45^{\circ} \mathrm{N}$, Aumento and Loubat, 1971. F. Z. = Fracture Zone.

Table 5. Whole-rock major element chemistry of serpentinized peridotites from Holes 556, 558, and 560 .

\begin{tabular}{|c|c|c|c|c|c|c|c|c|}
\hline \multirow{2}{*}{$\begin{array}{c}\text { Hole } \\
\text { Core-Section } \\
{\text { (interval in } \mathrm{cm})^{\mathrm{a}}}^{\mathrm{a}}\end{array}$} & \multicolumn{3}{|c|}{556} & \multicolumn{2}{|c|}{558} & \multicolumn{3}{|c|}{560} \\
\hline & $\begin{array}{c}13-1 \\
64-68\end{array}$ & $\begin{array}{c}14-1 \\
61-65\end{array}$ & $\begin{array}{c}14-2 \\
78-84\end{array}$ & $\begin{array}{c}41-3 \\
111-116\end{array}$ & $\begin{array}{c}42-1 \\
57-59\end{array}$ & $\begin{array}{c}4-1 \\
60-65^{b}\end{array}$ & $\begin{array}{c}4-1 \\
60-65^{b}\end{array}$ & $\begin{array}{c}5-1 \\
101-105\end{array}$ \\
\hline \multicolumn{9}{|c|}{ Major elements (wt. $\%$ ) } \\
\hline $\mathrm{SiO}_{2}$ & 39.89 & 37.10 & 40.56 & 37.72 & 38.12 & 39.21 & 39.30 & 39.58 \\
\hline $\mathrm{TiO}_{2}$ & 0.02 & 0.02 & 0.05 & 0.02 & 0.02 & 0.02 & 0.02 & 0.02 \\
\hline $\mathrm{Al}_{2} \mathrm{O}_{3}$ & 0.82 & 0.75 & 1.34 & 0.77 & 0.72 & 0.84 & 0.87 & 0.71 \\
\hline $\mathrm{Fe}_{2} \mathrm{O}_{3} \mathrm{C}$ & 8.09 & 7.61 & 9.12 & 6.67 & 7.29 & 6.61 & 6.78 & 7.09 \\
\hline $\mathrm{MnO}$ & 0.10 & 0.10 & 0.14 & 0.07 & 0.11 & 0.08 & 0.08 & 0.07 \\
\hline $\mathrm{MgO}$ & 37.34 & 34.37 & 35.56 & 37.39 & 39.53 & 39.06 & 39.27 & 39.73 \\
\hline $\mathrm{CaO}$ & 0.32 & 4.00 & 0.38 & 2.01 & 0.08 & 0.01 & 0.01 & 0.00 \\
\hline $\mathrm{Na}_{2} \mathrm{O}$ & 0.15 & 0.07 & 0.19 & 0.12 & 0.15 & 0.09 & 0.06 & 0.06 \\
\hline $\mathrm{K}_{2} \mathrm{O}$ & 0.00 & 0.00 & 0.01 & 0.00 & 0.00 & 0.00 & 0.00 & 0.00 \\
\hline $\operatorname{LOI}^{d}$ & 12.91 & 15.70 & 13.26 & 16.07 & 13.03 & 12.86 & 12.86 & 13.37 \\
\hline Total & 99.64 & 99.72 & 100.61 & 100.84 & 99.05 & 98.78 & 99.25 & 100.63 \\
\hline
\end{tabular}

Note: Precision and accuracy are $\pm 2 \%$ for elements over $5 \%$ concentration, $\pm 5 \%$ for elements 1 $5 \%$ concentration, and $\pm 50 \%$ or more for elements less than $0.5 \%\left(\mathrm{Na}_{2} \mathrm{O}, \mathrm{TiO}_{2}, \mathrm{CaO}, \mathrm{MnO}\right.$, $5 \%$ concen
and $\mathrm{K}_{2} \mathrm{O}$ ).

aEach sample represents $-25 \mathrm{~cm}^{3}$ of material.

beplicate analyses of powder splits from the same sample; indicates reproducibility.

cAssumes all ires as $\mathrm{Fe}^{3+}$

dyolatile loss on ignition between 110 and $1050^{\circ} \mathrm{C}$; includes $\mathrm{H}_{2} \mathrm{O}$ and $\mathrm{CO}_{2}$.

suggests systematic regional differences in upper mantle mineral chemistry and modes. The differences between the peridotite protoliths may be related either to greater degree of partial melting in the northernmost region or to preexisting heterogeneities in the mantle, as further discussed elsewhere (Michael and Bonatti, 1983; Dick and Bryan, 1983; Michael and Bonatti, in preparation).

\section{NOTE ADDED IN PROOF}

Subsequent sampling of peridotites from Hole 560 revealed the presence of primary orthopyroxene porphyroclasts averaging $2.8 \%$ $\mathrm{Al}_{2} \mathrm{O}_{3}$ and $91.1 \mathrm{Mg} /(\mathrm{Mg}+\mathrm{Fe}) \times 100$.

\section{ACKNOWLEDGMENTS}

This research was supported by NSF Grant OCE $80-25252$ and ONR Contract N000-80-0098T. Contribution No. 3572 from Lamont-Doherty Geological Observatory.

\section{REFERENCES}

Arai, S., and Fujii, T., 1979. Petrology of ultramafic rocks from Site 395. In Melson, W. G., Rabinowitz, P. D., et al., Init. Repts. DSDP, 45: Washington (U.S. Govt. Printing Office), 587-593.

Aumento, F., and Loubat, H., 1971. The Mid-Atlantic Ridge near $45^{\circ} \mathrm{N}$. XVI. Serpentinized ultramafic intrusions. Can., J. Earth Sci., 8:631-663.

Bonatti, E., 1976. Serpentinite protrusions in the oceanic crust. Earth Planet. Sci. Lett., 32:107-113.

Dick, H. J. B., 1975. Alpine peridotites and the oceanic lithosphere, a comparison. EOS, Trans. Am. Geophys. Union, 56:1077.

Dick, H. J. B., and Bryan, W. B., 1983. Contrasting abyssal basalt liquidus trends and regional variations in the composition of abyssal peridotites. EOS, Trans. Am. Geophys. Union, 64:310.

Francis, T. J., 1981. Serpentinization faults and their role in the tectonics of slow-spreading ridges. J. Geophys. Res., 86:11616-11622.

Hamlyn, P. R., and Bonatti, E., 1980. Petrology of mantle-derived ultramafics from the Owen Fracture Zone, Northwest Indian Ocean: implications for the nature of the oceanic upper mantle. Earth Planet. Sci. Lett., 48:65-79.

Harvey, P. K., Taylor, D. M., and Hendry, R. D., and Bancroft, F., 1973. An accurate fusion method for the analysis of rocks and chemically related materials by X-ray fluorescence spectrometry. $X$-ray Spectrom., 2:33-44.

Hoffman, M. A., and Walker, D., 1978. Textural and chemical variations of olivine and chrome spinel in the East Dover ultramafic bodies, south-central Vermont. Geol. Soc. Am. Bull., 89:699-710.

Jaques, A. L., and Green, D. H., 1980. Anhydrous melting of peridotite at $0-15 \mathrm{~Kb}$ pressure and the genesis of tholeiitic basalts. Contrib. Mineral. Petrol. 73:287-310.

Michael, P. J., and Bonatti, E., 1983. Peridotites from DSDP Leg 82 and Oceanographer F. Z. EOS, Trans. Am. Geophys. Union, 64:345.

Mysen, B. O., and Kushiro, I., 1977. Compositional variations of coexisting phases with degree of melting of peridotite in the upper mantle. Am. Mineral., 62:843-865.

Ozawa, K., 1983. Evaluation of olivine-spinel geothermometry as an indicator of thermal history for peridotites, Contrib. Mineral. Petrol., 82:52-65.

Pritchard, H. M., 1979. A petrographic study of the process of serpentinisation in ophiolites and the ocean crust. Contrib. Mineral. Petrol., 68:231-241.

Sigurdsson, H., and Schilling, J. G., 1976. Spinels in Mid-Atlantic Ridge basalts: chemistry and occurrence. Earth Planet. Sci. Lett., 29:7-20.

Sinton, J. M., 1979. Petrology of (alpine-type) peridotites from Site 395. In Melson, W. G., Rabinowitz, P. D., et al., Init. Repts. DSDP, 45: Washington (U.S. Govt. Printing Office), 595-601.

Smith, D., 1977. The origin and interpretation of spinel-pyroxene clusters in peridotite, $J$. Geol., 85:476-482.

Date of Initial Receipt: 12 August 1983

Date of Acceptance: 19 August 1983 